ISSN: 2542-0259

(C) Российское конкурентное право и экономика, 2019

\section{А.Н. Астанин,} Банк ВТБ (ПАО), Ассоциация антимонопольных экспертов,

г. Москва

\section{Проблемы внедрения системы антимонопольного комплаенса в компании}

\begin{abstract}
Аннотация
Настоящая статья раскрывает практические аспекты внедрения в компании антимонопольного комплаенса. Автор подробно раскрывает основные этапы внедрения антимонопольного комплаенса, заостряет внимание на проблемах, которые могут возникнуть на каждом этапе. Статья освещает процессы проведения внутренних служебных расследований, а также содержит практические советы по организации эффективного обучения сотрудников.
\end{abstract}

Ключевые слова: антимонопольный комплаенс, смягчение административной ответственности, антимонопольные расследования, антимонопольный аудит.

\title{
Problems of implementation of antitrust compliance in the company
}

\section{A. N. Astanin, \\ VTB Bank (PJSC), \\ Competition Experts Association, Moscow}

\begin{abstract}
Annotation
The article reveals the practical aspects of implementation of antitrust compliance in a company. The author describes in detail the main stages of the implementation of antitrust compliance, focuses on the problems that may arise at each stage. The article covers the processes of internal investigations, and contains practical advice on how to conduct effective employee training.
\end{abstract}

Keywords: antitrust compliance, mitigation of administrative responsibility, antitrust investigations, antitrust audit.

дним из основных трендов для современного бизнеса с начала 70-х гг. прошлого века является транспарентность [1, с. 19-46]. Любая компания, независимо от размера и дохода, стремится или вынуждена позиционировать себя в качестве хозяйствующего субъекта, который соблюдает законы и на основе справедливой конкурентной борьбы завоевывает внимание потребителей.

Еще пару лет назад антимонопольный комплаенс (compliance) был для российских компаний белым пятном и воспринимался как некая очередная экзотическая западная конструкция, которая неприменима для «суровых» российских реалий.

Тем не менее, несмотря на общий скепсис относительно антимонопольного комплаенса, на замораживание инициативы ФАС России об обязательном антимонопольном комплаенсе в статусе «вечного» законопроекта, все больше компаний задумывается и внедряет собственные системы такого комплаенса. Причем если первые системы напоминали, скорее, памятку с картинками для работников, то в настоящий момент у компаний появилась потребность в разработке «рабочих» документов, регламентирующих внутреннюю организационную форму, порядок работы ответственного подразделения, допустимые и недопустимые практики, порядок работы с запросами ФАС России, ответственность работников, порядок организации работы горячей линии и правила рассмотрения случаев нарушения антимонопольного законодательства. 
Проблемы внедрения системы антимонопольного комплаенса в компании

Одновременно появилось значительное число научных публикаций, посвященных различным аспектам внедрения антимонопольного комплаенса.

Прежде всего это обусловлено тем, что четкая модель антимонопольного комплаенса позволяет не только правильно наладить взаимоотношения с поставщиками, дистрибьюторами, потребителями, конкурентами, минимизировать претензии государственных органов, но и повысить уровень корпоративной культуры и транспарентности, уровень инвестиционной привлекательности и, как следствие, повысить капитализацию компании в целом.

Антимонопольный комплаенс, как и любая система, состоит из совокупности элементов, которые в итоге образуют единую структуру и формируют определенную целостность. В соответствии с законопроектом «О внесении изменений в Федеральный закон «О защите конкуренции» (далее - Законопроект) под антимонопольным комплаенсом понимается совокупность правовых и организационных мер, направленных на соблюдение антимонопольного законодательства и предупреждение нарушений внутри компании / группы компаний. Эти меры устанавливаются посредством принятия внутренних локальных актов (кодексы, политики, приказы о назначении ответственных лиц и т.д.) [ 5, с. 55-64). Так, системы антимонопольного комплаенса в качестве внутренних локальных нормативных актов приняты во многих иностранных и российских компаниях, например, в ООО Эппл Рус, ООО «Самсунг Электроникс Рус Компани», ПАО «ГМК “Норильский никель”», Группы компаний «ДИКСИ», ПАО «МТС», АО «Фармстандарт» и т.д.

Законопроект определяет перечень комплаенс-процедур, которые, по мнению антимонопольного органа, в обязательном порядке должны быть включены в систему антимонопольного комплаенса. К ним относятся:

- регулярная оценка рисков нарушения антимонопольного законодательства;

- меры по снижению этих рисков;

- меры по контролю за функционированием системы антимонопольного комплаенса;

- порядок ознакомления работников с внутренними актами, принятыми в рамках внедрения системы антимонопольного комплаенса;

- назначение должностных лиц, ответственных за функционирование системы антимонопольного комплаенса.

Учитывая отсутствие нормативного регулирования антимонопольного комплаенса, список его элементов носит открытый характер. Тем не менее в уже сложившейся практике принято выделять указанные в законопроекте элементы антимонопольного комплаенса.

\section{Проведение анализа соблюдения хозяйствующим субъектом норм законодательства (due diligence)}

Прежде чем внедрять любую систему комплаенса в компании, необходимо провести анализ хозяйственной дея- тельности на предмет ее соответствия нормам законодательства и наличия существующих рисков (due diligence). В зависимости от товарного рынка, на котором присутствует компания, проверке подлежат:

1. Взаимоотношения с конкурентами.

Как правило, типичными нарушениями антимонопольного законодательства в данной сфере являются:

- заключение картельного соглашения;

- сговор на торгах;

- осуществление согласованных действий.

2. Взаимоотношения с дилерами, дистрибьюторами, поставщиками (контрагентами).

В рассматриваемых отношениях действия компаний часто соответствуют таким признакам нарушений антимонопольного законодательства, как:

- заключение незаконных «вертикальных» соглашений;

- осуществление незаконной экономической координации.

3. Взаимоотношения с потребителями.

Типичными рисками в рамках взаимоотношений с потребителями являются нарушения:

- закона о рекламе;

- законодательства о защите прав потребителей.

4. Взаимодействие с органами государственной власти.

Нарушения при соответствующем взаимодействии могут быть в том числе связаны с:

- нарушениями конкуренции на торгах;

- получением преференций.

5. Деятельность компании в области M\&A

Крупные компании, входящие в большие группы лиц в порядке ст. 9 Федерального закона от 26.07.2006 № 135-Ф3 «0 защите конкуренции» (далее - Закон о защите конкуренции) и часто совершающие сделки, подпадают под государственный контроль за экономической концентрацией, регулируемый гл. 7 Закона о защите конкуренции и иными нормативными актами'. Несоблюдение порядка согласования сделок с антимонопольным органом может привести к штрафам, а также оспариванию соответствующих сделок.

\section{Карта рисков}

Результатом оценки хозяйственной деятельности компании и возникающих в связи с этим антимонопольных рисков является карта рисков. Данный документ отражает шкалу вероятности наступления конкретного риска при ведении предпринимательской деятельности (классификацию рисков от запрещенных действий до действий, которые потенциально могут быть незаконными) и возможный ущерб в случае антимонопольного расследования.

См.: Федеральный закон от 26.07.2006 № 135-Ф3 «0 защите конкуренции» // Собрание законодательства РФ, 31.07.2006, № 31 (ч. 1), ст. 3434 
При этом под возможным ущербом следует понимать не только вероятный денежный административный штраф, но и возможность предъявления претензий со стороны конкурентов, а именно обращения в суд с исками о взыскании убытков в связи с нарушением антимонопольного законодательства. Немаловажным риском являются последствия для репутации компании.

\section{Структура антимонопольного комплаенса}

По результатам проведения due diligence и формирования карты рисков необходимо определить структуру внутреннего документа, который будет регламентировать систему антимонопольного комплаенса в компании.

На практике любой документ, носящий статус декларации, работать не будет, поэтому под каждый раздел антимонопольного комплаенса необходимо разрабатывать детальные положения, которые будут описывать конкретные процедуры и действия ответственных сотрудников.

Таким образом, в зависимости от товарного рынка, на котором присутствует компания, для построения эффективной системы антимонопольного комплаенса требуется не только антимонопольная политика, но и система документов, регулирующих взаимоотношения как внутри компании, так и вовне. Как правило, эффективная система антимонопольного комплаенса включает в себя следующие документы, регламентирующие как внутренние, так и внешние взаимоотношения:

- коммерческая политика;

- политика соблюдения антимонопольного законодательства;

- правила взаимодействия с конкурентами;

- правила взаимодействия с дистрибьюторами, дилерами, ретейлерами;

- правила взаимодействия с должностными лицами государственных (муниципальных) органов власти;

- правила взаимодействия с потребителями;

- положение об органе (должностных лицах), ответственных за соблюдение компанией антимонопольного законодательства;

- положение о проведении аудита (мониторинга, оценки рисков) в сфере соблюдения компанией антимонопольного законодательства;

- положение о порядке проведения служебных расследований по факту нарушения антимонопольного законодательства.

\section{Антимонопольный аудит}

Важно отметить, что для эффективной системы антимонопольного комплаенса необходимо проработать механизм выявления антимонопольных рисков, а именно порядок проведения антимонопольного аудита хозяйственной деятельности, который представляет собой комплекс мероприятий, направленных на выявление и оценку антимоно- польных рисков, возникающих у компании при осуществлении предпринимательской деятельности.

Антимонопольный аудит может проводиться путем:

- проверки информации о случаях нарушения законодательства;

- общего мониторинга деятельности подразделений хозяйствующего субъекта;

- мониторинга конкретной деятельности хозяйствующего субъекта с учетом понимания существующих рисков;

- проведения интервью с руководителями подразделений хозяйствующего субъекта;

- систематического анкетирования работников, чья деятельность может быть связана с рисками нарушения антимонопольного законодательства;

- получения юридических заключений от внешних экспертов относительно деятельности хозяйствующего субъекта, которая может быть связана с рисками нарушения антимонопольного законодательства;

- получения разъяснений законодательства в ФАС России.

Результатом проведения антимонопольного аудита является заключение об итогах проведенного антимонопольного аудита. На практике данный документ может содержать следующие сведения:

- описание объекта антимонопольного аудита;

- сроки проведения аудита;

- использованный способ проведения антимонопольного аудита;

- описание порядка проведенного антимонопольного аудита;

- описание выявленных антимонопольных рисков;

- описание доказательств, на основании которых сделан вывод о наличии антимонопольных рисков;

- описание возможных негативных последствий для хозяйствующего субъекта;

- описание рекомендаций по минимизации рисков;

- вывод о необходимости / отсутствии необходимости проведения служебного расследования.

Также важно детально проработать механизм проведения служебных расследований, а именно комплекс мероприятий, направленных на выяснение всех обстоятельств, связанных с получением информации о возможном нарушении работниками и, как следствие, компанией антимонопольного законодательства, их фиксацию, юридическую квалификацию, оценку возможных негативных последствий. Разработка детального порядка проведения служебного расследования позволяет дать объективную оценку действиям компании и/или работников, в которых присутствуют признаки нарушения антимонопольного законодательства. Как правило, соответствующие локальные акты содержат права и обязанности ответственного за служебное расследование подразделения, описывают порядок проведения расследования, а также процесс принятия решений. 
Проблемы внедрения системы антимонопольного комплаенса в компании

\section{Обучение}

Подготовить политику - это задача комплаенс-подразделения и юридического департамента. Внедрение любой системы комплаенса - это сложный процесс, требующий немалых трудозатрат и объединения большого количества смежных подразделений компании.

Основным способом доведения информации о системе комплаенса в компании является обучение. Обучение может проводиться как очно, так и офлайн. Очные тренинги предусматривают проведение лекций, семинаров, на которых изучается как теоретическая, так и практическая часть. Целесообразно после тренинга в любом формате проводить тестирование сотрудников. При этом рекомендуется проходить тестирование до тех пор, пока сотрудник не получит положительную оценку.

Параллельно с тестированием необходимо предусмотреть контроль за прохождением сотрудниками обучения.

Важно проводить тренинги на регулярной основе, причем как для рядовых сотрудников, так и для топ-менеджеров.

Постоянный вопрос, возникающий на практике, заключается в том, как стимулировать сотрудников неформально относиться к тренинговым мероприятиям, посвященным комплаенсу. На практике комплаенс-офицеры применяют различные способы стимулирования, а также регулярно варьируют семинары.

Так, в одном из крупнейших мировых концернов составляется публичный рейтинг прохождения тренингов и успешный процент тестируемых. Соответствующее неформальное внутреннее соревнование стимулирует работников ответственно подходить к процессу изучения «скучных» документов. Одновременно с позитивным рейтингом возможно организовать так называемую доску позора.

При подготовке тренинга очень важно понимать, для кого он предназначается. Следует разграничивать контент для «чайников», которые находятся вне зоны риска нарушения комплаенс-процедур, и материалы для менеджеров, чьи трудовые функции могут потенциально привести к комплаенс-рискам.

Наиболее эффективными с точки зрения реальных знаний являются очные встречи с менеджерами. Это вызвано в том числе тем, что на практике работники, даже понимая, что сталкиваются с потенциальным риском, не хотят использовать электронную почту и компрометировать себя.

Помимо этого, до и после проведения семинаров рекомендуется проводить выборочные тесты сотрудников разного уровня. Это позволит осуществить срез знаний.

Нелишним будет подготовить информационную составляющую. Распространение дайджестов, подготовка плакатов, а также FAQ позволят привлечь внимание к системе комплаенса и стимулировать работников уделять этому внимание.

Проведение тренингов в формате тимбилдингов и квестов, разработка игровых материалов также способствуют успешному внедрению комплаенса в компании.

\section{Вывод}

Система антимонопольного комплаенса - сложный механизм, настройка которого потребует полного анализа деятельности компании и налаживания внутрикорпоративных взаимоотношений. Тем не менее, запустив систему антимонопольного комплаенса в компании, собственники в итоге минимизируют риски нарушения антимонопольного законодательства, стимулируют транспарентность деятельности компании и, как следствие, способствуют капитализации компании.

\section{Литература}

1. Lucas R. Econometric Policy Evaluation: A Critique // Carnegie - Rochester Conference Series on Public Policy. 1976. № 1. P. 19—46.

2. Соколов А.С. Практика внедрения системы антимонопольного комплаенса в инфраструктурном холдинге «Автодор» // Юрист. 2017. № 17. С. 15-18.

3. Молчанов А.В. Антимонопольный комплаенс: значение и перспективы правового регулирования // Юрист. 2017. № 17. С. 11-14.

4. Щерба Т. Э. Антимонопольный комплаенс в России. Понятие. Виды // СПС КонсультантПлюс. 2018.

5. Попондопуло В. Ф., Петров Д. А. Антимонопольный комплаенс: современное состояние и перспективы // Информационно-аналитический журнал «Арбитражные споры». 2019. № 2. С. 55-64.

6. Ашфа Д.М. Система внутреннего обеспечения соответствия требованиям антимонопольного законодательства в России: проблемы и перспективы развития правового регулирования // Актуальные проблемы российского права. 2019. № 4. С. 87-94.

7. Законопроект № 789090-7 «О внесении изменений в Федеральный закон “О защите конкуренции”».

\section{Сведения об авторе}

Астанин Андрей Николаевич: руководитель проекта, Банк ВТБ (ПАО ), член Ассоциации антимонопольных экспертов

Контактная информация:

Адрес: 123112, г. Москва, Пресненская наб., д. 12

Тел.: +7 (926) 569-86-84

E-mail: astan_rus@rambler.ru 